\title{
Synthesis and Characterization of New Complex Salts of Some Transition Metals with Pyrrolium Salts
}

\author{
Nabeel H. Buttrus Isra A. Saeed \\ Department of Chemistry, College of Science \\ Mosul University, Mosul - Iraq
}

Received

Accepted

$16 / 12 / 2002$

$25 / 2 / 2003$

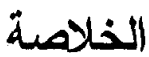

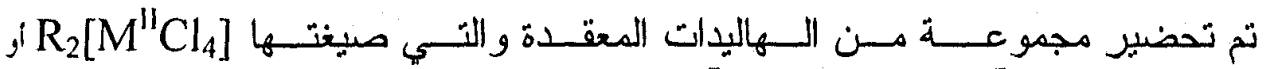

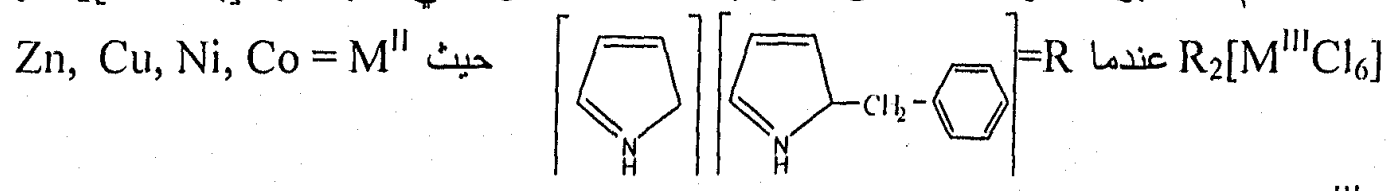

$. \mathrm{Cr}, \mathrm{Fe}=\mathrm{M}^{\prime \prime \prime}$,

من دراسة التوصيل الكهرباني، وطيف الأشعة تحت الحمر اء وطيف الأشــعة فــوق

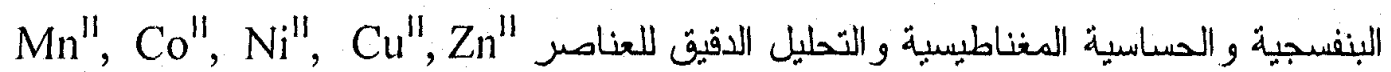

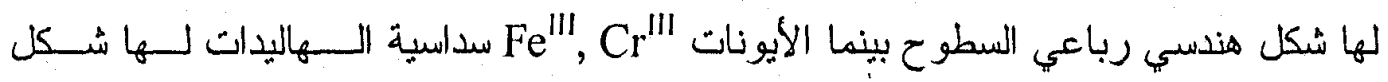
هندسي ثماني السطوح.
\end{abstract}

\section{ABSTRACT}

The preparation of series of complex chloride of the type $\mathrm{R}_{2}\left[\mathrm{M}^{\mathrm{II}} \mathrm{Cl}_{4}\right]$ or $\mathrm{R}_{2}\left[\mathrm{M}^{\mathrm{III}} \mathrm{Cl} \mathrm{l}_{6}\right]$, when $\mathrm{R}=$

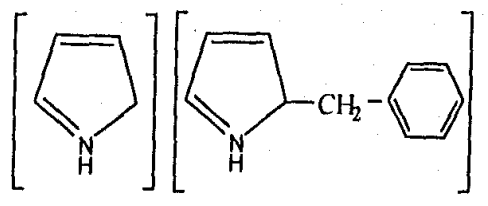

$\mathrm{M}^{\mathrm{II}}=\mathrm{Mn}, \mathrm{Co}, \mathrm{Ni}, \mathrm{Cu}, \mathrm{Zn}, \mathrm{M}^{\mathrm{III}}=\mathrm{Fe}$, and $\mathrm{Cr}$ has been carried out.

The conductivity, IR, Uv-visible spectra, magnetic susceptibility and elemental microanalysis of pyrrolium complex salts have been studied and it is concluded that tetra chloro complex salts of $\mathrm{Mn}^{\mathrm{II}}, \mathrm{Co}$, $\mathrm{Ni}^{\mathrm{il}}, \mathrm{Cu}^{\mathrm{II}}$ have tetrahedral geometry, while $\mathrm{Cr}^{\mathrm{III}}$ and $\mathrm{Fe}^{\mathrm{III}}$ are hexa chloro complex salts were obtained and have octahedral geometry. 


\section{INTRODUCTION}

Fused salts that are liquid at room temperature are in unconventional but interesting class of aprotic solvents for studying the chemistry of inorganic, organometallic, and organic solvents. In addition, these ionic liquids are potentially useful as electrolytes in batteries, photoelectrochemical cells, electroplating and electrochemistry (1-3).

In recent years some mixtures of 1,3 dialkylimidazolium chloride with $\mathrm{AlCl}_{3}$ have been reported to be molten at or near room temperature $(4,5)$. The applications of aluminium based ionic liquid as solvents for transition metal complexes and in electrochemistry are limited because these ionic liquids are moisture sensitive and, moreover, most of transition metal complexes and organic substrates are not inert to the organo-aluminte compounds. Air and water stable molten can be obtained by the substitution of the chloro-aluminate anion by weakly complexing anions as $\mathrm{BF}_{4}$ (6), $\mathrm{PF}_{6}$ (7) and $\mathrm{CF}_{3} \mathrm{SO}_{3}$ (8) in the 1-ethyl-3methylimidazolium compound.

Koronaios and Osteryoung (9) showed that, a series of studies on the activity of $\mathrm{AlCl}_{3}$-1-ethyl-3-methylimidazolium chloride melts buffered with alkali metal chlorides, it is possible to explain many of the acidity and latent acidity results on the basis of the solubility products of the alkali metal chlorides.

We report here the preparation and properties of new complex salts of some transition metals with pyrrolium salts which has improved electrochemical and physical properties.

\section{EXPERIMENTÁL}

IR spectra were recorded on a Perkin Elmer 580BIR spectrophotometer in the range $4000-200 \mathrm{~cm}^{-1}$ using CsI discs. Elemental analyses were carried out on a CHN analyser type 1106 (Carlo Erba). Conductivity measurement were made on $10^{-3} \mathrm{M}$ solutions of the complex salts in DMSO at room temperature $\left(25^{\circ} \mathrm{C}\right)$ using conductivity meter model PCM3-Jenway. Electronic spectra were recorded on a shimadzu Uv-vis spectrophotometer Uv- 160 for $10^{-3} \mathrm{M}$ solutions of the complex salts in DMSO at room temperature $\left(25^{\circ} \mathrm{C}\right)$ using $1 \mathrm{~cm}$ quartz cell. Magnetic measurements were carried out at $\left(25^{\circ} \mathrm{C}\right)$ by the Faraday method on the solid complexes in pyrex tube Burker B.M.6 instrument.

The first series of transition metal chlorides were used as supplied by Fluka. All reagents used were chemically pure or analytical grade. Solvents were purified and dried according to standard procedures. 


\section{Preparation of 2-benzylpyrrolium chloride}

To a stirred solution of benzyl chloride $(1.26 \mathrm{~g}, 0.01 \mathrm{~mol})$ in ethanol $\left(10 \mathrm{~cm}^{3}\right)$ was added dropwise to a solution of $(0.67 \mathrm{~g}, 0.01)$ pyrrole in $(10$ $\mathrm{cm}^{3}$ ) ethanol for $30 \mathrm{~min}$. the reaction mixture was refluxed for $2 \mathrm{~h}$. the mixture was left for 3 days at room temperature and the brown solid thus formed was filtered off, washed twice with ethanol $\left(2 \times 10 \mathrm{~cm}^{3}\right)$ and ether $\left(10 \mathrm{~cm}^{3}\right)$, then dried under vacuum for $3 \mathrm{~h}$.

\section{Preparation of complex salts}

The complex salts were prepared by using following methods:

1. Preparation of tris(2-benzylpyrrolium) hexa chloro chromate (III).

The salt $\mathrm{CrCl}_{3} .6 \mathrm{H}_{2} \mathrm{O}(0.27 \mathrm{~g}, 0.001 \mathrm{~mol})$ was dissolved in ethanol $\left(10 \mathrm{~cm}^{3}\right)$. The resulting solution was added slowly with stirring to a solution of the salt 2-benzylpurrolium chloride (2-bpc) $(0.58 \mathrm{~g}, 0.003 \mathrm{~mol})$ in methylcyanide $\left(15 \mathrm{~cm}^{3}\right)$. The mixture was refluxed for $2 \mathrm{~h}$., then the solution was allowed to cool to room temperature. The solid thus formed was filtered off, washed with ethanol $\left(10 \mathrm{~cm}^{3}\right)$, followed by ether $\left(10 \mathrm{~cm}^{3}\right)$ and dried under vacuum for $\mathrm{ca} 3 \mathrm{~h}$.

The rest of the complex salts having general formula [2-bpc $]_{2}\left[\mathrm{MCl}_{4}\right]$. When $\mathrm{M}^{(\mathrm{II})}=\mathrm{Mn}, \mathrm{Co}, \mathrm{Ni}, \mathrm{Cu}$ and $\mathrm{Zn}$ were prepared in similar manner, except that the equimolar quantities of 2-benzylpyrrolium chloride $(2.0 \mathrm{mmol})$ was used.

\section{Direct method}

Preparation of tris-pyrrolium hexa chloro chromate (III).

The salt $\mathrm{CrCl}_{3} .6 \mathrm{H}_{2} \mathrm{O}(0.27 \mathrm{~g}, 0.001 \mathrm{~mol})$ was dissolved in ethanol $\left(10 \mathrm{~cm}^{3}\right)$. The resulting solution was added to a solution of $(2.01 \mathrm{~g}, 0.03)$ of pyrrole in ethanol $\left(10 \mathrm{~cm}^{3}\right)$. Then concentrated $\mathrm{HCl}$ was added dropwise, with stirring until the $\mathrm{pH}$ of the solution was (2.5-3.0). the mixture was left with stirring for $2 \mathrm{~h}$., Then left for 3 days. The solid thus formed, was filtered off, washed with ethanol $\left(10 \mathrm{~cm}^{3}\right)$, followed by ether $\left(10 \mathrm{~cm}^{3}\right)$ and dried under vacuum for $3 \mathrm{~h}$. 


\section{RESULTS AND DISCUSSION}

The reaction of 2-benzylpyrrolium chloride or pyrrolium chloride with metal salts in ethanol at room temperature afforded after 7.2 hours complex salts in high yields (scheme 1).

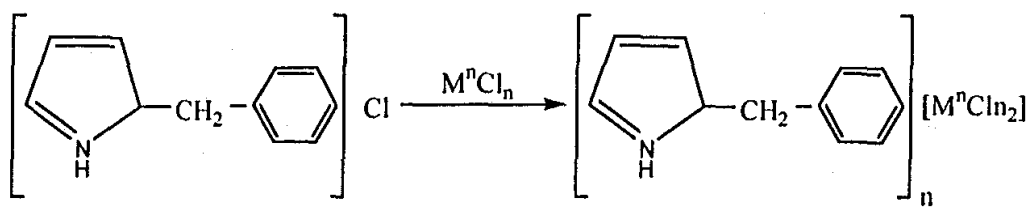

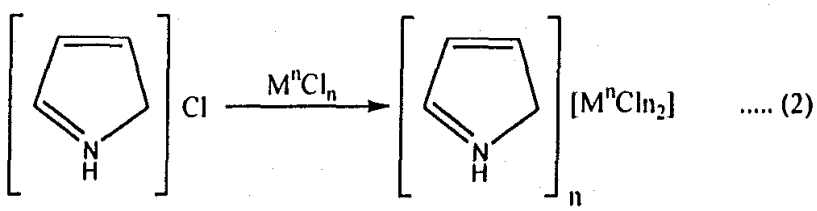

$\mathrm{n}=2, \mathrm{M}=\mathrm{Mn}, \mathrm{Co}, \mathrm{Ni}, \mathrm{Cu}$ and $\mathrm{Zn}$ $\mathrm{n}=3, \mathrm{M}=\mathrm{Cr}$ and $\mathrm{Fe}$

\section{Scheme 1. Synthesis of complex salts}

The methods used in the preparation were normally efficient for the synthesis of the complex salts by eq (1) and (2).

The complex salts are stable, non hydroscopic, dark coloured solids. The melting points, elemental analyses and conductance measurements are listed in Table 1.

The conductance data show that the complex salts are $2: 1$ or $3: 1$ electrolytes. Conductivity were measured also at various concentrations, the plot $\Lambda_{\mathfrak{e}}$ vis $\varpi \epsilon \rho \sigma v \sigma \mathrm{N}^{1 / 2}$ being linear over the concentration range 10$0.1 \mathrm{mM}$. A and $\Lambda_{0}$ values $\left(330-345 \mathrm{ohm}^{-1} \mathrm{~cm}^{2}\right.$ equiv ${ }^{-1} \mathrm{~N}^{-1 / 2}$ and $102-108$ ohm $^{-1} \mathrm{~cm}^{2}$ equiv ${ }^{-1} \mathrm{~N}^{-1 / 2}$, respectively) from the Onsager equation $\Lambda_{0}=\Lambda_{\mathrm{e}}+\mathrm{AN}^{1 / 2}$ agree with those for $2: 1$ or $3 ; 1$ electrolytes (10).

The conductivities of the complex salts are significantly higher than those observed for the 1-n-butyl-3-methylimidazolium tetrachloroalumininates (11). This indicates the interaction between the anion and cation is essentially electrostatic with a small contribution of the hydrogen bands. 


\section{Infrared spectra}

Table 2 shows the more characteristic infrared spectral bands of the organic salts and their complex salts. The assignment of the infrared spectra of the organic salt show a band at 2650 and $1628 \mathrm{~cm}^{-1}$, assigned to $v\left(\mathrm{~N}^{+}-\mathrm{H}\right)(12)$ and $v(\mathrm{C}+\mathrm{N})(13)$ respectively. The spectra of the complex slats also reveal the presence of the above bands at similar position as well as the presence of new band observed at $235-333 \mathrm{~cm}^{-1}$ which was assigned to $\mathrm{v}(\mathrm{M}-\mathrm{Cl})(14)$.

The results of the magnetic moment measurements presented in Table 2. Throw light on the sterochemistry of these complex salts. The magnetic moment for $\mathrm{Cr}$ complex salts, were found to be 3.68 and 3.97B.M. corresponding to the spin octahedral $\mathrm{Cr}$ (III) complex salts, while the Fe (III). complex salts showed a magnetic moments of 5.74 and 5.96 B.M., which is in fair agreement for high spin octahedral Fe (II) complex salts.

In the case of Mn (II) complex salts the magnetic moments were found to be 5.71 and 5.92 B.M. corresponding to high spin tetrahedral $\mathrm{Mn}$ (II) complex salts (15).

The Co (II) complex salts have magnetic moments values of 4.98 and 4.79 B.M. corresponding to high spin tetrahedral Co (II) complex salts (16).

The magnetic moment of $\mathrm{Ni}$ (II) complex salts were found to be 4.27 and 3.92 B.M. suggest the presence of two unpaired electrons, which correspond to tetrahedral geometry around $\mathrm{Ni}$ (II) complex salts.

The magnetic moment of $\mathrm{Cu}$ (II) complex salts have been found 2.05 and 2.12 B.M., which is in agreement for tetrahedral $\mathrm{Cu}$ (II) geometry.

\section{Electronic spectra}

Three bands gave been observed for the Cr (II) complex salts at (29069 and 30581) and (23809-21786) and (14925-15625) $\mathrm{cm}^{-1}$. These may be assigned ${ }^{4} \mathrm{~A}_{2} \mathrm{~g} \longrightarrow{ }^{4} \mathrm{~T}_{1} \mathrm{~g}(\mathrm{P})\left(\mathrm{U}_{3}\right),{ }^{4} \mathrm{~A}_{2} \mathrm{~g} \longrightarrow{ }^{4} \mathrm{~T}_{1} \mathrm{~g}(\mathrm{~F})\left(\mathrm{U}_{2}\right)$, and ${ }^{4} \mathrm{~A}_{2} \mathrm{~g} \longrightarrow{ }^{4} \mathrm{~T}_{2} \mathrm{~g}(\mathrm{~F})\left(\mathrm{U}_{1}\right)$, which is in good agreement with the values for octahedral Cr (III) complex salts (17).

In $\mathrm{Fe}$ (III) complex salts two bands are observed at (23419-23584) and (29525-24911) $\mathrm{cm}^{-1}$ corresponding to the transition ${ }^{6} \mathrm{~A}_{1} \mathrm{~g} \rightarrow{ }^{4} \mathrm{~T}_{2} \mathrm{~g}$ (G) $\left(\mathrm{U}_{2}\right)$ and ${ }^{6} \mathrm{~A}_{1} \mathrm{~g} \longrightarrow{ }^{4} \mathrm{Eg}(\mathrm{G})\left(\mathrm{U}_{3}\right)$ respectively. These values suggest high spin octahedral geometry.

In Mn (II) complex salts, two strong bands are observed at (2252225062) and (29069-37037) $\mathrm{cm}^{-1}$ which are assigned to ${ }^{6} \mathrm{~A}_{1} \longrightarrow{ }^{4} \mathrm{E}(\mathrm{D})$ and ${ }^{6} \mathrm{~A}_{1} \longrightarrow{ }^{4} \mathrm{E}(\mathrm{G})$ excitations, respectively. Moderate intensity of these bands is indicative of tetrahedral geometry (18). 
Co(II) complex salts, two bands at (14705-16600) and (16286$20533) \mathrm{cm}^{-1}$ are assigned to ${ }^{4} \mathrm{~A}_{2} \longrightarrow{ }^{4} \mathrm{~T}_{1}(\mathrm{P})$ excitation which suggest tetrahedral geometry.

$\mathrm{Ni}(\mathrm{II})$ complex salts, exhibits two bands at (12610-15384) and (14388-20491) $\mathrm{cm}^{-1}$ which may be assigned to ${ }^{3} \mathrm{~T}_{1}(\mathrm{~F}) \longrightarrow{ }^{3} \mathrm{~T}_{1}(\mathrm{P})\left(\mathrm{U}_{3}\right)$ and suggest tetrahedral geometry.

$\mathrm{Cu}(\mathrm{II})$ complex salts: Two bands are observed at (11416-19762) and (23866-25510) $\mathrm{cm}^{-1}$ which may be assigned to ${ }^{2} \mathrm{~B}_{1} \mathrm{~g} \longrightarrow{ }^{2} \mathrm{Eg}$ indicating tetrahedral geometry around the $\mathrm{Cu}(\mathrm{II})$.

The complex salts of $\mathrm{Zn}$ (II) are diamagnetic do not show d-d transition. The information on their structure derived from conductivity measurements.

In view of the spectral observations taken together with analytical data, magnetic moments and molar conductance, we propose the following structures for the complex salts:<smiles>Cl[W](Cl)(Cl)Cl</smiles><smiles>Cl[W](Cl)(Cl)(Cl)(Cl)Cl</smiles>

$$
\mathrm{M}=\mathrm{Mn}(\mathrm{II}), \mathrm{Co}(\mathrm{II}), \mathrm{Ni}(\mathrm{II}) \quad \mathrm{M}=\mathrm{Fe}(\mathrm{III}) \text {, and } \mathrm{Cr}(\mathrm{III})
$$

$\mathrm{Co}(\mathrm{II})$ and $\mathrm{Zn}(\mathrm{II})$ 
Table 1: Analytical, magnetic moments and conductance data for the organic salts and complex salts.

\begin{tabular}{|c|c|c|c|c|c|c|c|}
\hline \multirow[b]{2}{*}{ Compound } & \multirow{2}{*}{$\begin{array}{c}\text { Melting } \\
\text { point } \\
\left({ }^{\circ} \mathrm{C}\right)\end{array}$} & \multirow{2}{*}{ Color } & \multicolumn{3}{|c|}{ Found (calc.)\% } & \multirow{2}{*}{$\begin{array}{c}\Lambda \\
\mathrm{ohm}^{-1} \mathbf{c m}^{-1} \mathrm{~mol}^{-1} \\
\end{array}$} & \multirow{2}{*}{$\begin{array}{c}\mathbf{M}_{\mathrm{eff}} \\
(\mathrm{B} . \mathrm{M})\end{array}$} \\
\hline & & & $\mathrm{C}$ & $\mathbf{H}$ & $\mathbf{N}$ & & \\
\hline (2-bpyc) & $180(d)$ & Brown & \begin{tabular}{|c|}
67.95 \\
$(68.23)$ \\
\end{tabular} & $\begin{array}{c}6.03 \\
(6.20) \\
\end{array}$ & $\begin{array}{c}7.08 \\
(7.24) \\
\end{array}$ & 38 & - \\
\hline$[2 \mathrm{bpc}]_{3}\left[\mathrm{CrCl}_{6}\right]$ & $270(d)$ & Black & \begin{tabular}{|c|}
65.40 \\
$(53.61)$ \\
\end{tabular} & $\begin{array}{c}4.62 \\
(4.87) \\
\end{array}$ & $\begin{array}{c}5.49 \\
(5.69) \\
\end{array}$ & 128 & 3.68 \\
\hline$[2 \mathrm{bpc}]_{3}\left[\mathrm{MnCl}_{4}\right]$ & 245 & Brown & $\begin{array}{c}50.88 \\
(51.49) \\
\end{array}$ & $\begin{array}{c}4.44 \\
(4.68) \\
\end{array}$ & $\begin{array}{c}5.19 \\
(4.49) \\
\end{array}$ & 88 & 5.71 \\
\hline$[2 \mathrm{bpc}]_{3}\left[\mathrm{FeCl}_{4}\right]$ & $255(d)$ & Black & $\begin{array}{c}53.11 \\
(53.33) \\
\end{array}$ & $\begin{array}{c}5.00 \\
(4.85) \\
\end{array}$ & $\begin{array}{c}5.41 \\
(5.66) \\
\end{array}$ & 76 & 5.96 \\
\hline$[2 \mathrm{bpc}]_{2}\left[\mathrm{CoCl}_{4}\right]$ & $230(d)$ & Black & $\begin{array}{c}50.88 \\
(51.09) \\
\end{array}$ & $\begin{array}{r}4.52 \\
(4.63) \\
\end{array}$ & $\begin{array}{r}5.19 \\
(5.42) \\
\end{array}$ & 78 & 4.98 \\
\hline$[2 \mathrm{bpc}]_{2}\left[\mathrm{NiCl}_{4}\right]$ & $247(d)$ & Black & \begin{tabular}{|c|}
50.98 \\
$(51.11)$ \\
\end{tabular} & $\begin{array}{r}4.59 \\
(4.65) \\
\end{array}$ & $\begin{array}{r}5.26 \\
(5.42) \\
\end{array}$ & 85 & 4.27 \\
\hline$[2 \mathrm{bpc}]_{2}\left[\mathrm{CuCl}_{4}\right]$ & $273(d)$ & Black & $\begin{array}{c}50.44 \\
(50.64) \\
\end{array}$ & $\begin{array}{c}4.51 \\
(4.60)\end{array}$ & $\begin{array}{c}5.18 \\
(5.37)\end{array}$ & 100 & 2.05 \\
\hline$[2 \mathrm{bpc}]_{2}\left[\mathrm{ZnCl}_{4}\right]$ & 220 & Brown & $\begin{array}{c}49.98 \\
(50.46) \\
\end{array}$ & $\begin{array}{c}4.49 \\
(4.59) \\
\end{array}$ & $\begin{array}{c}5.19 \\
(5.35) \\
\end{array}$ & 84 & Dia \\
\hline$\left[\left.\mathrm{py}\right|_{3} \mid \mathrm{CrCl}_{6}\right]$ & 87 & $\begin{array}{l}\text { Dark } \\
\text { green }\end{array}$ & \begin{tabular}{|c|}
30.98 \\
$(30.72)$ \\
\end{tabular} & $\begin{array}{c}4.01 \\
(3.89) \\
\end{array}$ & $\begin{array}{r}8.65 \\
(8.96) \\
\end{array}$ & 133 & 3.97 \\
\hline$|\mathrm{py}|_{2}\left[\mathrm{MnCl}_{4}\right]$ & 54 & Brown & \begin{tabular}{|c|}
28.64 \\
$(28.85)$ \\
\end{tabular} & $\begin{array}{c}3.49 \\
(3.61) \\
\end{array}$ & $\begin{array}{r}8.36 \\
(8.42) \\
\end{array}$ & 92 & 5.92 \\
\hline$|\mathrm{py}|_{3}\left[\mathrm{FeCl}_{6}\right]$ & 180 & Black & $\begin{array}{c}30.22 \\
(30.47) \\
\end{array}$ & $\begin{array}{c}4.01 \\
(3.81)\end{array}$ & $\begin{array}{c}8.60 \\
(8.89) \\
\end{array}$ & 131 & 5.74 \\
\hline$[\mathrm{py}]_{2}\left[\mathrm{CoCl}_{4}\right]$ & 65 & $\begin{array}{l}\text { Pale } \\
\text { green }\end{array}$ & $\begin{array}{c}28.22 \\
(28.51) \\
\end{array}$ & $\begin{array}{c}3.46 \\
(3.56)\end{array}$ & $\begin{array}{c}8.21 \\
(8.32)\end{array}$ & 79 & 4.79 \\
\hline$[\mathrm{py}]_{2}\left[\mathrm{NiCl}_{4}\right]$ & 97 & Black & $\begin{array}{c}28.11 \\
(28.53) \\
\end{array}$ & $\begin{array}{c}3.66 \\
(3.57) \\
\end{array}$ & $\begin{array}{c}8.02 \\
(8.32) \\
\end{array}$ & 86 & 3.92 \\
\hline$[p y]_{2}\left[\mathrm{CuCl}_{4}\right]$ & $176(d)$ & Brown & \begin{tabular}{|c|}
28.01 \\
$(28.12)$ \\
\end{tabular} & $\begin{array}{c}3.42 \\
(3.52)\end{array}$ & $\begin{array}{c}8.03 \\
(8.20)\end{array}$ & 79 & 2.12 \\
\hline$[\mathrm{py}]_{2}\left[\mathrm{ZnCl}_{4}\right]$ & 232 & & \begin{tabular}{|c|}
27.60 \\
$(27.97)$ \\
\end{tabular} & $\begin{array}{r}3.32 \\
(3.50) \\
\end{array}$ & $\begin{array}{c}7.98 \\
(8.16)\end{array}$ & 73 & Dia \\
\hline
\end{tabular}

$\mathrm{d}=$ decomposition temperature 
Table 2: IR absorption $\left(\mathrm{cm}^{-1}\right)$ and Electronic data for the complex salts.

\begin{tabular}{|c|c|c|c|c|}
\hline \multirow{2}{*}{ Compound } & \multicolumn{3}{|c|}{ IR } & \multirow{2}{*}{$\begin{array}{l}\text { Uv/visible band } \\
\text { maxima in }\left(\mathrm{cm}^{-1}\right)\end{array}$} \\
\hline & $v(\mathbf{N H})^{+}$ & $v(C=N)$ & $v(\mathrm{M}-\mathrm{Cl})$ & \\
\hline (2-bpyc) & $2560(s)$ & $1658(\mathrm{~s})$ & - & 32070 \\
\hline$[2 \mathrm{bpc}]_{3}\left[\mathrm{CrCl}_{6}\right]$ & $2556(\mathrm{~m})$ & $1628(\mathrm{w})$ & $322(w)$ & $14925,23809,29069$ \\
\hline$\left[2 \mathrm{bpc}_{3}\left[\mathrm{MnCl}_{4}\right]\right.$ & $2540(\mathrm{~s})$ & 1619(s) & $311(w)$ & 25062,29069 \\
\hline$[2 \mathrm{bpc}]_{3}\left[\mathrm{FeCl}_{4}\right]$ & $2560(w)$ & $1628(w)$ & $290(\mathrm{~s})$ & 23419,29525 \\
\hline$[2 \mathrm{bpc}]_{2}\left[\mathrm{CoCl}_{4}\right]$ & $2540(w)$ & $1628(\mathrm{~m})$ & $383(\mathrm{~s})$ & 16600,20533 \\
\hline$[2 \mathrm{bpc}]_{2}\left[\mathrm{NiCl}_{4}\right]$ & $2540(w)$ & $1620(\mathrm{~s})$ & $285(w)$ & 15384,20491 \\
\hline$\left[2 \mathrm{bpc}_{2}\left[\mathrm{CuCl}_{4}\right]\right.$ & $2520(\mathrm{~m})$ & $1628(\mathrm{~m})$ & $256(\mathrm{~s})$ & 19762,236866 \\
\hline$[2 \mathrm{bpc}]_{2}\left[\mathrm{ZnCl}_{4}\right]$ & 2540(w) & $1623(\mathrm{~m})$ & $260(s)$ & 23866,29325 \\
\hline$\left[\left.\mathrm{py}\right|_{3} \mid \mathrm{CrCl}_{6}\right]$ & $2540(w)$ & 1634(s) & $320(w)$ & $15384,23809,29154$ \\
\hline$[p y]_{2}\left[\mathrm{MnCl}_{4}\right]$ & $2560(w)$ & $1640(w)$ & $290(w)$ & 22522,37037 \\
\hline$[\mathrm{py}]_{3}\left[\mathrm{FeCl}_{6}\right]$ & $2540(w)$ & $1628(w)$ & $280(w)$ & 23519,29411 \\
\hline$\left[\left.\mathrm{py}\right|_{2}\left[\mathrm{CoCl}_{4}\right]\right.$ & $2500(w)$ & $1614(\mathrm{~s})$ & $270(s)$ & 14705,16286 \\
\hline$\left.|p y|_{2} \mid \mathrm{NiCl}_{4}\right]$ & $2540(w)$ & $1628(\mathrm{~s})$ & $250(w)$ & 12610,14388 \\
\hline$|\mathrm{py}|_{2}\left[\mathrm{CuCl}_{4}\right]$ & $2540(w)$ & $1638(\mathrm{~s})$ & $300(w)$ & 11416,25510 \\
\hline$[\mathrm{py}]_{2}\left[\mathrm{ZnCl}_{4}\right]$ & $2510(w)$ & $1619(w)$ & $275(w)$ & 22522,31645 \\
\hline
\end{tabular}

\section{REFERENCES}

1. Wilkes J.S. ; Levisky, J. A. ; Wilson, R.A. and Hussey, C.L. Inorg. Chem. 12: 1263 (1982).

2. Hussey C.L. "Advanced in Molten Salt Chemistry" Elserier New York, (1983).

3. Hussey C.L. Pure Appl. Chem. 60: 1763 (1988).

4. Clum H.L. ; Koch, V.R. ; Milier, L.L. and Osteryounng, R.A. J. Am. Chem. Soc., 97: 3264 (1975).

5. Hussey C.L. ; King, L.A. and Carpio, C.A. J. Electrochem. Soc., 1: 1029, (1979).

6. Wilkes J.S. and Zaworotko, M.J. J. Chem. Soc. Chem. Commun. 965, (1992).

7. Fuller J. ; Carlin, R.T. ; De Long, H.C. and Haworth, D. J. Chem. Soc. Chem. Commun. 299, (1994).

8. Suarez P.A.Z. ; Einloft, S. ; Dullius, J.E.L. ; DeSouza, R.F. and Dupont, J. J. Chim. Phys. 95: 1626, (1998).

9. Koronaios P. and Osteryonng, R.A. J. Electrochem. Soc., 147: 3414, (2000).

10. Geary W.J. Coord. Chem. Rev., 7: 81, (1971). 
11. Fannin A.A. ; Floreani, D.A. ; King, L.A. ; Londers, J.S. ; Piersma, B.J. ; Wikes, J.S. and Williams, J.K. J. Phys. Chem., 88: 2614, (1984).

12. Nakanishi K. "Infrared Absorption Spectroscopy" $1^{\text {st }}$ Ed. Japan, (1962).

13. Joule J.A. and Smith, G.F. "Heterocyclic Chemistry" $1^{\text {st }}$ ed. Van Nordtand Reinhold London, (1972).

14. Nakamoto K. "Infrared and Raman Spectra of Inorganic and Coordination Compounds" $5^{\text {th }}$ ed. Wiely-Luterscience, New York, (1997).

15. Harriman A. Coord. Chem. Rev., 28: 147, (1979).

16. Randhawa S. ; Punnu, B.S. and Chopra, S.L. J. Indian Chem. Soc. LX, 112, (1983).

17. Figgis B.N. "Introduction to Ligand Field" London, (1976).

18. Gansi N.R. and Munshi, K.N. J. Indian Chem. Soc. LIX, 1290, (1982). 


\title{
Existence of a Periodic Solution for Nonlinear Systems of Differential Equations with Retarded Argument
}

\author{
Raad N. Butris $\quad$ Ayad S. Seeto \\ Department of Mathematics \\ College of Education \\ Mosul University
}

Received

Accepted

$6 / 9 / 2003$

$20 / 12 / 2003$

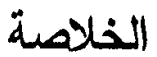

يتضنمن البحث دراسة وجود وتقارب الحلول الدورية لنظم من المعادلات التفاضليــة

غير الخطية ذات تأخر المتغير المستقل وذلك باستخدام طريقة الحلول الدوربـــة للمعسادلات

التفاضلية الاعنيادية لـ A. M. Samoilenko
\end{abstract}

\begin{abstract}
In this paper we investigate the existence and approximation of the periodic solutions for nonlinear systems of differential equations with retarded argument, by using the method of periodic solutions of ordinary differential equation which are given be A. M. Somilenko .
\end{abstract}

\section{INTRODUCTION}

Consider the following system of differential equations with retarded argument:

$$
\frac{d x(t)}{d t}=f\left(t, x(t), x(t-\tau), \frac{d x(t)}{d t}, \frac{d x(t-\tau)}{d t}\right),
$$

where the function $f\left(t, x, x_{\tau}, y, y_{\tau}\right)$ is defined on the domain:

$$
\begin{aligned}
& -\infty<t<\infty, \quad a \leq x(t) \leq b, \quad a \leq x(t-\tau)=x_{\tau} \leq b, \\
& c \leq y=\frac{d x(t)}{d t} \leq d, \quad c \leq \frac{d x(t-\tau)}{d t}=y_{\tau} \leq d, \quad 0 \leq \tau \leq T,
\end{aligned}
$$

which is continuous in $t, x, x_{\tau}, y, y_{\tau}$ and periodic in $t$ of period $T$. 